\title{
OVERVIEW OF ELECTROCHEMICAL POWER SOURCES FOR ELECTRIC AND HYBRID-ELECTRIC VEHICLES
}

by

Dennis W. Dees

Chemical Technology Division

Electrochemical Technology Program

Argonne National Laboratory

9700 South Cass Avenue

Argonne, IL 6043 U.S.A.

The submitted manuscript has been created by the University of
Chicago as Operator of Argonne National Laboratory ("Argonne")
under Contract No. W-31-109-ENG-38 with the U.S. Department of
Energy. The U.S. Government retains for itself, and others acting
on its behalf, a paid-up, nonexclusive, Irrevocable worldwide
license in said article to reproduce, prepare derivative works,
distribute copies to the public, and perform publicly and display
publicly, by or on behalf of the Government.

publicly, by or on behalf of the Government.

\section{January 1999}

As requested by special invitation for the Special Session on Electric Vehicle Technology by Professor C.C. Chan, University of Hong Kong, for IEEE-IEMDC 99, May 9-12, 1999, Cavanaugh's Hotel, Seattle, WA.

This work was supported by the U.S. Department of Energy, Office of Basic Energy Science, Chemical Sciences Division and the Office of Transportation Technologies, Office of Automotive Technologies under Contract No. W-31-109-ENG-38. 


\section{DISCLAIMER}

This report was prepared as an account of work sponsored by an agency of the United States Government. Neither the United States Government nor any agency thereof, nor any of their employees, make any warranty, express or implied, or assumes any legal liability or responsibility for the accuracy, completeness, or usefulness of any information, apparatus, product, or process disclosed, or represents that its use would not infringe privately owned rights. Reference herein to any specific commercial product, process, or service by trade name, trademark, manufacturer, or otherwise does not necessarily constitute or imply its endorsement, recommendation, or favoring by the United States Government or any agency thereof. The views and opinions of authors expressed herein do not necessarily state or reflect those of the United States Government or any agency thereof. 


\section{DISCLAIMER}

Portions of this document may be illegible in electronic image products. Images are produced from the best available original document. 


\title{
Overview of Electrochemical Power Sources for Electric and Hybrid-Electric Vehicles
}

\author{
Dennis W. Dees \\ Chemical Technology Division \\ Electrochemical Technology Program \\ Argonne National Laboratory \\ 9700 South Cass Avenue \\ Argonne, IL 60439 U.S.A.
}

Electric and hybrid-electric vehicles are being developed and commercialized around the world at a rate never before $\operatorname{seen}^{(1-5)}$. These efforts are driven by the prospect of vehicles with lower emissions and higher fuel efficiencies. The widespread adaptation of such vehicles promises a cleaner environment and a reduction in the rate of accumulation of greenhouse gases. Critical to the success of this technology is the use of electrochemical power sources such as batteries and fuel cells, which can convert chemical energy to electrical energy more efficiently and quietly than internal combustion engines. This overview will concentrate on the work being conducted in the United States to develop advanced propulsion systems for the electric and hybrid vehicles. This work is spearheaded by the United States Advanced Battery Consortium (USABC) for electric vehicles and the Partnership for a New Generation of Vehicle (PNGV) for hybrid-electric vehicles, both of which can be read about on the world wide web (www.uscar.com).

As is commonly known, electric vehicles rely strictly on batteries as their source of power. Hybrid-electric vehicles, however, have a dual source of power. An internal combustion engine or eventually a fuel cell supplies the vehicle with power at a relatively constant rate. A battery pack (much smaller than a typical electric-vehicle battery pack) provides the vehicle with its fast transient power requirements such as during acceleration. This hybrid arrangement maximizes vehicle fuel efficiency. Electric and hybrid-electric vehicles will also be able to convert the vehicle's change in momentum during braking into electrical energy and store it in its battery pack (instead of lose the energy as heat). This process, known as regenerative braking, will add to the vehicle's fuel efficiency in an urban environment.

\section{FUEL CELL TECHNOLOGY}

Fuel cells have been around for more than one hundred years, but it was the development work by NASA for the space program that made them into practical electrochemical power sources. These fuel cells continuously convert oxygen and hydrogen into electricity and water. While there are several different types of fuel cell technologies, the one being seriously considered for hybrid-electric vehicles is the polymer electrolyte membrane (PEM) fuel cell. Conceptually the PEM fuel cell stack is relatively simple in design. Individual cells are connected in series through graphite bipolar plates, which contain the flow fields for the reactant and product gasses. The cells are made of a protonconducting polymer electrolyte sandwiched between electrodes made of polymer and carbon loaded with a platinum catalyst.

Under the present plan for the PNGV Program, the fuel cell-powered car will operate on conventional as well as alternative fuels. Complex hydrocarbon fuels are not really compatible with the PEM fuel cell technology. Thus, it is necessary to have a significant amount of on-board fuel processing, which converts hydrocarbon fuels to hydrogen with relatively low levels of carbon monoxide (a poison to the fuel cell catalyst). The challenge, then, is to build a safe, dependable, compact, and lightweight system that will efficiently convert hydrocarbon fuels to electrical power at a price that the consumer is willing to pay. To accomplish this, a diverse program is underway on system integration, as well as development of the PEM stack system, fuel processing, stack components and materials, on-board hydrogen storage, and air management systems.

On the fuel cell side of the system, efforts are being concentrated on reducing individual cell costs through highspeed manufacturing techniques, making further reductions in what is already a low catalyst loading, increasing carbon monoxide tolerance, and lowering cell operating pressure while maintaining performance. New composite bipolar plates of molded carbon are being developed, which would significantly reduce the cost of the fuel cell stack. In the area of fuel processing technology, partial-oxidation reformers are being developed, which will work with a wide variety of fuels and produce a hydrogen-rich stream at low carbon monoxide levels. Individual system components are being integrated and operated to demonstrate the viability and costeffectiveness of the technology.

\section{BATTERY TECHNOLOGY}

Historically, primarily because of its availability and cost, lead-acid has been the type of battery most frequently used in electric vehicles. Over the last twenty years a number of alkaline electrolyte batteries containing a hydrated nickel 
oxide positive electrode have been developed with varying degrees of success (e.g., nickel/cadmium, nickel/iron, nickel/zinc, and nickel/metal hydride). Of these, the nickel/metal hydride battery is generally considered the most promising, and commercially available electric and hybridelectric vehicles can be purchased today with nickel/metal hydride battery packs. Other aqueous electrolyte battery systems currently being tested in electric vehicles include zinc/bromine and zinc/air.

Because of their potential for low cost and high power and energy, there has been considerable interest in hightemperature advanced batteries over the last twenty years for electric vehicles. These include lithium/iron sulfide (molten salt electrolyte), sodium/sulfur, and sodium/nickel chloride (ceramic electrolyte). In the last five years, the sodium/nickel chloride battery has emerged as the most promising and mature of the high-temperature batteries and is currently available in electric vehicles sold in Europe.

Today, the most promising advanced battery technologies for electric and hybrid-electric vehicles are the organic electrolyte batteries based on lithium, which offer high power and energy and operate at room or near room temperature. The best known, because they are commercially available for portable electronic applications, is the lithium-ion technology, which is being tested for electric vehicles by a number of developers. This technology has a liquid electrolyte and shuttles lithium ions between two intercalation electrodes (a metal oxide positive and a carbon negative). Another advanced battery system being tested at the pack level is the lithium-polymer battery. This system has a metallic lithium negative (a metal oxide positive) and a dry polymer electrolyte.

\section{CONCLUSIONS}

Today's electric vehicles contain a variety of battery systems. Even more advanced systems will be available shortly after the turn of the century. A number of these battery systems will meet the public's expectations for range and performance. Their acceptance into the mainstream will be determined in large part by cost. The next decade will also bring the advent of the hybrid-electric vehicle powered by a fuel cell and battery system. Like the electric vehicle cost will also likely be the determining factor in its acceptance.

\section{REFERENCES}

1. Electric and Hybrid Vehicle Technology '97, UK and International Press (1997)

2. Electric and Hybrid Vehicle Technology '98, UK and International Press (1998)

3. Proceedings of the 32nd Intersociety Energy Conversion Engineering Conference, IECEC-97, vol.2 (1997)
4. The $14^{\text {th }}$ International Electric Vehicle Symposium and Exhibition Proceedings, EVS-14 (1997)

5. The $15^{\text {th }}$ Intemational Electric Vehicle Symposium and Exhibition Proceedings, EVS-15 (1998) 